\title{
ANTASed - An Updated Sediment Model for Antarctica
}

\author{
A. Baranov ${ }^{1 *}$, A. Morelli ${ }^{2}$ and A. Chuvaev ${ }^{3}$ \\ ${ }^{1}$ Schmidt Institute of Physics of the Earth, Russian Academy of Sciences, Moscow, Russia, ${ }^{2}$ Istituto Nazionale di Geofisica e \\ Vulcanologia, Sezione di Bologna, Bologna, Italy, ${ }^{3}$ Institute of Earthquake Prediction Theory and Mathematical Geophysics, \\ Russian Academy of Sciences, Moscow, Russia
}

\section{OPEN ACCESS}

Edited by:

Xiubin Lin,

Zhejiang University, China

Reviewed by:

Luis E. Lara,

Servicio Nacional de Geología y Minería de Chile (SERNAGEOMIN),

Chile

Luigi Jovane,

University of São Paulo, Brazil

${ }^{*}$ Correspondence:

A. Baranov

baranov@ifz.ru

Specialty section:

This article was submitted to

Structural Geology and Tectonics,

a section of the journal

Frontiers in Earth Science

Received: 09 June 2021

Accepted: 28 July 2021

Published: 10 August 2021

Citation:

Baranov A, Morelli $A$ and Chuvaev $A$ (2021) ANTASed - An Updated

Sediment Model for Antarctica.

Front. Earth Sci. 9:722699.

doi: 10.3389/feart.2021.722699
We compile existing seismic, gravity, radar and magnetic data, together with the subglacial bedrock relief from the BEDMACHINE project, to build the most detailed sediment model for Antarctica. We interpolate these data according to a tectonic map of Antarctica using a statistical kriging method. Our results reveal significant sediment accumulation in Antarctica with several types of sedimentary basins: parts of the Beacon Supergroup and more recent rifting basins. The basement relief closely resembles major geological and tectonic structures. The thickness of sediments has significant variations around the continent, and depends on the degree of crustal extension. West Antarctica has wide sedimentary basins: the Ross basin (thickness 2-6 km), the Filchner-Ronne basin $(2-12 \mathrm{~km})$ with continuations into East Antarctica, the Bentley Subglacial Trench and the Byrd basin (2-4 km). The deepest Filchner-Ronne basin has a complex structure with multi-layered sediments. East Antarctica is characterized by vast sedimentary basins such as the Pensacola-Pole (1-2 km), Coats Land (1-3 km), Dronning Maud Land (1-2 km), Vostok (2-7 km), Aurora (1-3 km), Astrolabe (2-4 km), Adventure (2-4 km), and Wilkes (1-4 km) basins, along with narrow deep rifts filled by sediments: JutulStraumen (1-2 km), Lambert $(2-5 \mathrm{~km})$, Scott, Denman, Vanderford and Totten $(2-4 \mathrm{~km})$ rifts. The average thickness of sediments for the whole continent is about $0.77 \mathrm{~km}$. The new model, ANTASed, represents a significant improvement over CRUST 1.0 for Antarctica, and reveals new sedimentary basins. Differences between ANTASed and CRUST 1.0 reach $+12 /-3 \mathrm{~km}$.

Keywords: sediments, Antarctica, Gondwana, Denman, Vanderford, Astrolabe, Adventure, Scott

\section{INTRODUCTION}

Sediments represent the most heterogeneous layer of the Earth's interior and their characteristics can mask the mantle signature in geophysical measurements. In addition, information on age and density of sediments is also important for geodynamical and gravity modeling. Most of the large sedimentary basins formed due to crustal extension (continental rifting), a process initiated by mantle convection (e.g. Hartley and Allen, 1994). Geophysical data provide important clues on basin structure and origin. Seismic, gravity, radar, magnetic, and subglacial relief data can be used to construct sedimentary thickness maps. Sediment properties, such as their density, can also be estimated using geophysical data, from which their load can be inferred as a parameter for determining isostatic balance. Considerable efforts to investigate the sediments have been undertaken in the past, but some parts of the world are still poorly studied, such as Antarctica. Here, the ice sheet is partly underlain by sedimentary basins, and knowledge of the subglacial sedimentary layer holds particular interest 
because of its role in glacier dynamics (e.g., Aster and Winberry, 2017) as sediments reduce basal friction and may thus favor basal sliding (Anandakrishnan et al., 1998). Also, low-lying subglacial sedimentary basins may be below sea level, and thus have important implications on ice sheet stability over global change (Studinger et al., 2001; Joughin and Alley, 2011). Global sediment models such as CRUST1.0 (Laske et al., 2013) and CRUST2.0 (Bassin et al., 2000) are poorly constrained in Antarctica. CRUST2.0 uses crustal types on a $2 \times 2$ Cartesian grid to specify sediment properties, including sediment thickness, while model CRUST1.0 uses the sediment model of Laske and Masters (1997) based on maps available at the time, including the 1985 AAPG Tectonic Map of the World assembled for Exxon (Laske et al., 2013). These global models obviously could not take into account the later maps of subglacial relief (Fretwell et al., 2013; Morlighem et al., 2020), magnetic and gravity data (e.g. Aitken, et al., 2014; Frederick et al., 2016; Scheinert et al., 2016; Golynsky and Golynsky 2019). A preliminary regional map of the total sediment thickness has been built by Baranov et al. (2018a). They found large basins of sediments, with maximum thickness under the Filchner-Ronne Ice Shelf $(14 \mathrm{~km})$. However, not all data had been taken into account at the time. In addition, that model has low detail in the interior regions. It is therefore important to update the sediment model for Antarctica using newly available geophysical data. Seismic tomographic images indicate cold, high seismic velocity, subcontinental mantle under East Antarctica (Danesi and Morelli, 2001; Becker, 2012; An et al., 2015) and a descending mantle flow (Chuvaev et al., 2020). On the contrary, under West Antarctica, according to tomographic models, we see presence of hot low-velocity upper mantle, and upwelling mantle flow (e.g., Morelli and Danesi, 2004; Lucas et al., 2020). Processes of extension and magmatism continue there at present time (Faccenna et al., 2008). West Antarctica is now a large zone of crustal extension, and can therefore be inferred as a vast area of sediment accumulation (Jordan et al., 2020).

Perhaps the most important tectonic feature of West Antarctica is the West Antarctic Rift System - a 500-600 km wide region of stretched continental crust that borders the Transantarctic Mountains (Davey et al., 2006; LeMasurier, 2008; Jordan et al., 2010; Granot et al., 2013a; Tinto et al., 2019; Jordan et al., 2020; Lucas et al., 2020). This rift system differs from other active rift systems in one important respect: it has very low (subglacial) relief (1,000-2,500 m below sea level). Rifting processes began during and before the Gondwana breakup, and in some places they continue till now (Granot et al., 2013b). Broad-mode Cretaceous rifting linked to the Gondwana breakup has been followed by narrow-mode Cenozoic rifting (Brink et al., 1993; Davey et al., 2006; Huerta and Harry, 2007). These processes have been accompanied by sediment accumulation (Hole and LeMasurier, 1994). The new BEDMACHINE detailed subglacial topography map (Morlighem et al., 2020) reveals some new features of the subglacial structure of Antarctica and creates the prerequisites for improving a sediment thickness map. In this study, we compile seismic, bedrock and other geophysical data to construct a new sediment model of Antarctica. The framework of our map is given by the BEDMACHINE subglacial relief (Morlighem et al.,
2020), and the gravity map from Scheinert et al. (2016). The data and the compilation technique are described in Data Compilation and Methods and Table 1. Results are described in Results. Discussion and concluding remarks are given in Discussion and Conclusion.

\section{DATA COMPILATION AND METHODS}

Seismic data for Antarctica are geographically rather sparse, especially in inland regions. However, we also resort to new gravity, radar, bedrock and magnetic data to infer information on shallow crustal structure in regions without seismic coverage. These data mainly provide indirect values for sediment thickness. However magnetic data allow a fairly accurate determination of sediment thickness i.e. depth to magnetic basement e.g. (Aitken et al., 2014). The data sources are presented in Table 1. They result in an uneven data distribution on the whole continent (Figure 1). Having collect suitable data, we analyse them, infer additional contours of sediment thickness according to the bedrock relief, and interpolate the data array onto a geographical grid, created with an azimuthal equidistant projection centered at the South Pole, with grid step $0.1^{\circ}$, using standard kriging (linear variogram; SURFER, Golden Software package). We limit the grid by the border of the Antarctic continent. This technique has been described in detail and applied to construct Moho models for Antarctica (Baranov and Morelli, 2013; Baranov et al., 2018a) and the crustal models for Central and Southern Asia (Baranov, 2010; Baranov et al., 2018b). We obtain seismic velocity information for sediments from Deep Seismic Sounding (DSS), wide-angle reflection, and refraction profiles (Table 1). We estimate uncertainties of such a model, using standard deviations (SURFER, Golden Software package). Although kriging standard deviations do not necessarily give an accurate picture of the interpolation prediction error (e.g., Cressie, 1990), we provide such a map in Figure 2. It can be interpreted as a proxy for the relative geographical reliability of our model. Nevertheless, we believe that the sediment map for Antarctica has significantly been improved by integrating many more information sources than in earlier studies.

\section{RESULTS}

It has been suggested that some of the present sedimentary basins in Antarctica began to form during and before Gondwana breakup from Permian age (Powell et al., 1988; Boger and Wilson, 2003) during the formation of the Beacon Supergroup (Collinson et al., 1994). The Beacon Supergroup experienced the intrusions of magmatic sills during the Gondwana breakup, after which sedimentation in the depressions continued and ceased in Eocene-Miocene due to ice covering the continent (Whitehead et al., 2006). Our results, based on geophysical data summarized in Data Compilation and Methods, are presented next. The resulting sediment thickness for Antarctica is shown in Figure 3A. 
TABLE 1 | Data sources used in this study.

\begin{tabular}{|c|c|c|c|c|c|c|c|c|c|}
\hline Region & $\begin{array}{c}\text { Total } \\
\text { sediment } \\
\text { thickness, km }\end{array}$ & $\begin{array}{c}\text { Upper } \\
\text { sediments, km }\end{array}$ & $\begin{array}{c}\text { Middle } \\
\text { sediments, km }\end{array}$ & $\begin{array}{c}\text { Lower } \\
\text { sediments, km }\end{array}$ & $\begin{array}{c}\text { Upper } \\
\text { sediments, } \\
\text { Vp, km/s }\end{array}$ & $\begin{array}{c}\text { Middle } \\
\text { sediments, } \\
\text { Vp, km/s }\end{array}$ & $\begin{array}{c}\text { Lower } \\
\text { sediments, } \\
\text { Vp, km/s }\end{array}$ & Source & Additionally \\
\hline Coats Land & $1-3$ & $1-2$ & $0-1$ & 0 & $4.3-4.4 ?$ & $?$ & - & $\begin{array}{l}\text { Bamber et al. (2006), } \\
\text { Shepherd et al. (2006), } \\
\text { Scheinert et al. (2016) } \\
\text { (Radio-echo sounding, } \\
\text { gravity and magnetic } \\
\text { data) }\end{array}$ & $\begin{array}{l}\text { Beacon } \\
\text { Supergroup? new } \\
\text { rifted sediments, } \\
\text { latitudinal strike }\end{array}$ \\
\hline $\begin{array}{l}\text { Dronning } \\
\text { Maud Land }\end{array}$ & $1-2$ & $1-2$ & - & - & 4.7 & - & - & $\begin{array}{l}\text { Hungeling and Tyssen } \\
\text { (1991), Scheinert et al. } \\
\text { (2016) (seismic and } \\
\text { gravity data) }\end{array}$ & $\begin{array}{l}\text { Local area near P2 } \\
\text { profile and for } \\
\text { Jutulstraumen Rift }\end{array}$ \\
\hline Lambert Rift & $2-5$ & 2 & $0-3$ & - & $3.4-3.5$ & $3.5-3.7$ & - & $\begin{array}{l}\text { Kolmakov et al., (1975) } \\
\text { (DSS profiles); Mishra et al. } \\
\text { (1999), Scheinert et al. } \\
\text { (2016) (gravity and magnetic } \\
\text { data) }\end{array}$ & $\begin{array}{l}\text { From Devon to } \\
\text { Cenozoic } \\
\text { sediments }\end{array}$ \\
\hline $\begin{array}{l}\text { Scott and } \\
\text { Denman rifts }\end{array}$ & $2-4$ & 2 & $0-2$ & - & $?$ & $?$ & - & $\begin{array}{l}\text { Golynsky and Golynsky } \\
\text { (2012), Scheinert et al. (2016) } \\
\text { (gravity data) }\end{array}$ & $\begin{array}{l}\text { From Devon to } \\
\text { Cenozoic } \\
\text { sediments }\end{array}$ \\
\hline Vostok Basin & $2-7$ & 2 & $2-5$ & - & $3.4-3.5$ & $3.6-3.7$ & - & $\begin{array}{l}\text { Isanina et al. (2009) (seismic } \\
\text { profile with converted } \\
\text { waves); Golynsky and } \\
\text { Golynsky (2012) (radar, } \\
\text { gravity and magnetic data) }\end{array}$ & $\begin{array}{l}\text { From Devon to } \\
\text { Cenozoic } \\
\text { sediments }\end{array}$ \\
\hline Aurora Basin & $1-3$ & $1-2$ & $0-1$ & - & $?$ & $?$ & $?$ & $\begin{array}{l}\text { Aitken et al. (2014) (radar, } \\
\text { gravity and magnetic data) }\end{array}$ & $?$ \\
\hline $\begin{array}{l}\text { Adventure } \\
\text { Trench }\end{array}$ & $2-4$ & 2 & $0-2$ & - & $?$ & $?$ & $?$ & $\begin{array}{l}\text { Ferraccioli et al. (2001), } \\
\text { Studinger et al. (2004) } \\
\text { (gravity and magnetic } \\
\text { data) }\end{array}$ & Rifted sediments? \\
\hline $\begin{array}{l}\text { Astrolabe } \\
\text { Subglacial } \\
\text { Basin }\end{array}$ & $2-4$ & 2 & $0-2$ & - & $?$ & $?$ & $?$ & $\begin{array}{l}\text { Aitken et al. (2014) (radar, } \\
\text { gravity and magnetic data) }\end{array}$ & Rifted sediments? \\
\hline $\begin{array}{l}\text { Vanderford } \\
\text { and Totten } \\
\text { rifts }\end{array}$ & $2-4$ & 2 & $0-2$ & - & $?$ & - & - & $\begin{array}{l}\text { Aitken, et al. (2014), } \\
\text { Golynsky and Golynsky } \\
\text { (2019) (radar, gravity and } \\
\text { magnetic data) }\end{array}$ & latitudinal strike \\
\hline $\begin{array}{l}\text { Wilkes } \\
\text { Subglacial } \\
\text { Basin }\end{array}$ & $1-4$ & $1-2$ & $0-2$ & - & 3.4 & $3.6-3.7 ?$ & - & $\begin{array}{l}\text { Ferraccioli et al. (2001), } \\
\text { Ferraccioli et al. (2009), } \\
\text { Frederick et al. (2016) } \\
\text { (radar, gravity and } \\
\text { magnetic data) }\end{array}$ & $\begin{array}{l}\text { Beacon } \\
\text { Supergroup, } \\
\text { Cenozoic marine } \\
\text { sediments? }\end{array}$ \\
\hline Ross Ice Shelf & $2-6$ & 2 & $0-4$ & - & $1.9-2.4$ & 4.2 & - & $\begin{array}{l}\text { Bentley (1973) (BB', DSS } \\
\text { profile); Rooney et al. (1987) } \\
\text { (two refraction profiles); } \\
\text { Brink et al. (1993) } \\
\text { (reflection, refraction and } \\
\text { gravity profile); Beaudoin } \\
\text { et al. (1992) (refraction } \\
\text { profile); Munson and } \\
\text { Bentley (1992) (reflection, } \\
\text { refraction and gravity } \\
\text { profile) }\end{array}$ & $\begin{array}{l}\text { Part of West } \\
\text { Antarctic Rift } \\
\text { System, Beacon } \\
\text { Supergroup, } \\
\text { Mezozoic- } \\
\text { Cenozoic } \\
\text { sediments }\end{array}$ \\
\hline $\begin{array}{l}\text { Byrd and } \\
\text { Bentley } \\
\text { Subglacial } \\
\text { basins }\end{array}$ & $2-4$ & 2 & $0-2$ & - & 4.1 & $4.2-4.3$ & - & $\begin{array}{l}\text { Bentley (1973) (BB', CC' } \\
\text { DSS profiles) }\end{array}$ & $\begin{array}{l}\text { Part of West } \\
\text { Antarctic Rift } \\
\text { System, Beacon } \\
\text { Supergroup, } \\
\text { Mezozoic- } \\
\text { Cenozoic } \\
\text { sediments }\end{array}$ \\
\hline $\begin{array}{l}\text { Filchner- } \\
\text { Ronne Basin }\end{array}$ & $2-12$ & 2 & $0-5$ & $0-7$ & $2.6-3.0$ & $3.3-4.0$ & $4.6-4.9$ & $\begin{array}{l}\text { Huebscher et al. (1996) (2 } \\
\text { refraction profiles); } \\
\text { Leitchenkov and } \\
\text { Kudryavtzev (1997) (DSS } \\
\text { profile); Golynsky and } \\
\text { Aleshkova (1997) } \\
\text { (magnetic data) }\end{array}$ & $\begin{array}{l}\text { Sediments of } \\
\text { terrigenous, marine } \\
\text { and glacial marine } \\
\text { origin }\end{array}$ \\
\hline $\begin{array}{l}\text { Pensacola- } \\
\text { Pole } \\
\text { Subglacial } \\
\text { Basin }\end{array}$ & $1-2$ & $1-2$ & - & - & $4.3-4.4 ?$ & - & - & $\begin{array}{l}\text { Bentley (1973) (AA' DSS } \\
\text { profile); Paxman et al. } \\
\text { (2019) (gravity, radar and } \\
\text { magnetic data) }\end{array}$ & $\begin{array}{l}\text { Beacon } \\
\text { Supergroup? }\end{array}$ \\
\hline
\end{tabular}




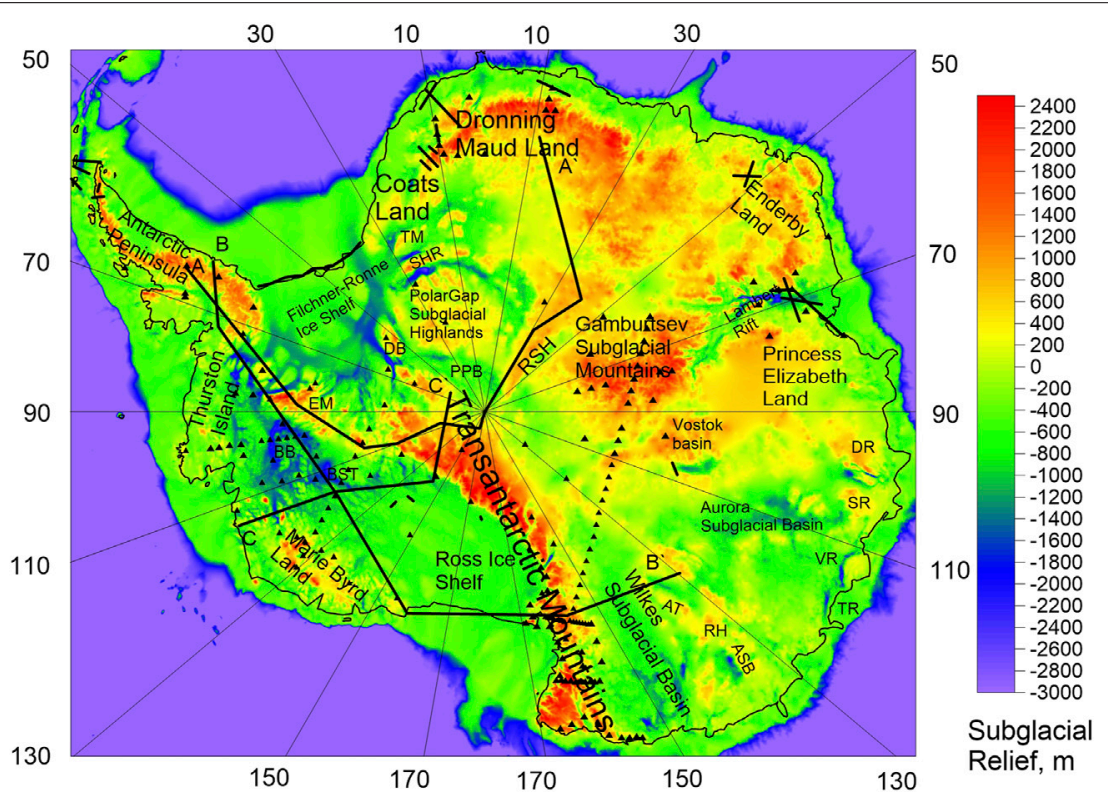

FIGURE 1 | Subglacial relief in Antarctica according to BEDMACHINE (Morlighem et al., 2020). Notation used: black triangles represent seismic stations; black lines represent seismic profiles. Used abbreviation: PPB, Pensacola-Pole Basin; EM, Ellsworth Mountains; BB, Byrd Basin; BST, Bentley Subglacial Trench; SHR, Shackleton Range; TM, Theron Mountains; SR, Scott rift; DR, Denman rift; VR, Vanderford rift; TR, Totten rift; AT, Adventure Trench; ASB, Astrolabe Subglacial Basin; RH, Resolution Highlands; DB, Dufek Block; RSH, Recovery Subglacial Highlands.

\section{East Antarctica}

East Antarctica has vast areas with low bedrock elevation and sedimentary basins. These basins can be divided into three blocks: the continuation of the Filchner-Ronne basin into East Antarctica, the sedimentary basins of the Indo-Antarctica and Australo-Antarctica blocks of East Antarctica. At the deep subglacial valleys between PolarGap Subglacial Highlands, Shackleton Range and Theron Mountains there are indications of a $2-3 \mathrm{~km}$ thick sedimentary layer, in continuation to the South Pole (Bamber et al., 2006; Shepherd et al., 2006; Scheinert et al., 2016). These sediments are believed to be part of the Paleozoic Beacon Supergroup (Collinson et al., 1994). A Permian sedimentary rock layer of about $1-2 \mathrm{~km}$ is found for the Western Dronning Maud Land, whereas on the P1, Novo, SAE33, SAE34 and Kottas seismic profiles sediments were not found (Kogan, 1971; Hungeling and Tyssen 1991; Kudryavtzev et al., 1991; Bayer et al., 2009). Part of the AA' profile from South Pole to the central part of Dronning Maud Land reveals no sediments (Bentley, 1973). No sediments are found at Enderby Land (Kanao et al., 2011). According to subglacial relief (Morlighem et al., 2020) and gravity data (Scheinert et al., 2016), we suggest $1-2 \mathrm{~km}$ of sediments for the narrow JutulStraumen rift.

Lambert Rift is a deep long subglacial valley with low relief and sediments about 2-5 km thick (Kolmakov et al., 1975; Mishra et al., 1999). The process of rifting started at Permian age and continued in the Mezozoic (Boger and Wilson, 2003; Lisker et al., 2003). Further, in addition to rifting, the area apparently also submerged. Terrestrial forested sediments have been found near the coast in Prydz Bay, with the first evidence for glaciation of Late Eocene age (Whitehead et al., 2006).

Scott and Denman are other long narrow rifts (Morlighem et al., 2020) with a possible continuation in Vostok subglacial Basin (Golynsky and Golynsky, 2012). It is suggested that these rifts are the continuation of the rift between India and Australia that developed during Gondwana break-up (Harrowfield et al., 2005). Lambert, Scott and Denman rifts have continuation in India (Holdgate et al., 2005). According to subglacial relief (Morlighem et al., 2020) and gravity data (Scheinert et al., 2016), we hence suggest $2-4 \mathrm{~km}$ of sediments for Scott and Denman trenches.

The seismic profile for the Vostok Basin near the coastline of the Vostok Lake provides sediment thickness of about $2-7 \mathrm{~km}$ (Isanina et al., 2009). A more recent study also reveals hard and soft sediments here (Filina et al., 2008).

The Aurora Subglacial Basin is characterized by low subglacial topography and deep trenches. It is a branching system of narrow basins in central East Antarctica trending northwest towards the Aurora coast. The inland system of deep trenches can be tracked over a distance of $1,000 \mathrm{~km}$ towards the Transantarctic Mountains under ice in the Aurora basin (Tabacco et al., 2006; Golynsky and Golynsky, 2019; Morlighem et al., 2020). Radar, gravity and magnetic data suggest $1-3 \mathrm{~km}$ of sediments for these trenches (Aitken et al., 2014; Scheinert et al., 2016).

Data from the ICECAP/IceBridge project outline the Vanderford and Totten deep subglacial trenches. These trenches are about $50 \mathrm{~km}$ wide and $400 \mathrm{~km}$ long, with very low subglacial relief (Aitken et al., 2014). It is also suggested that the Vanderford and Totten trenches are another rift that, 


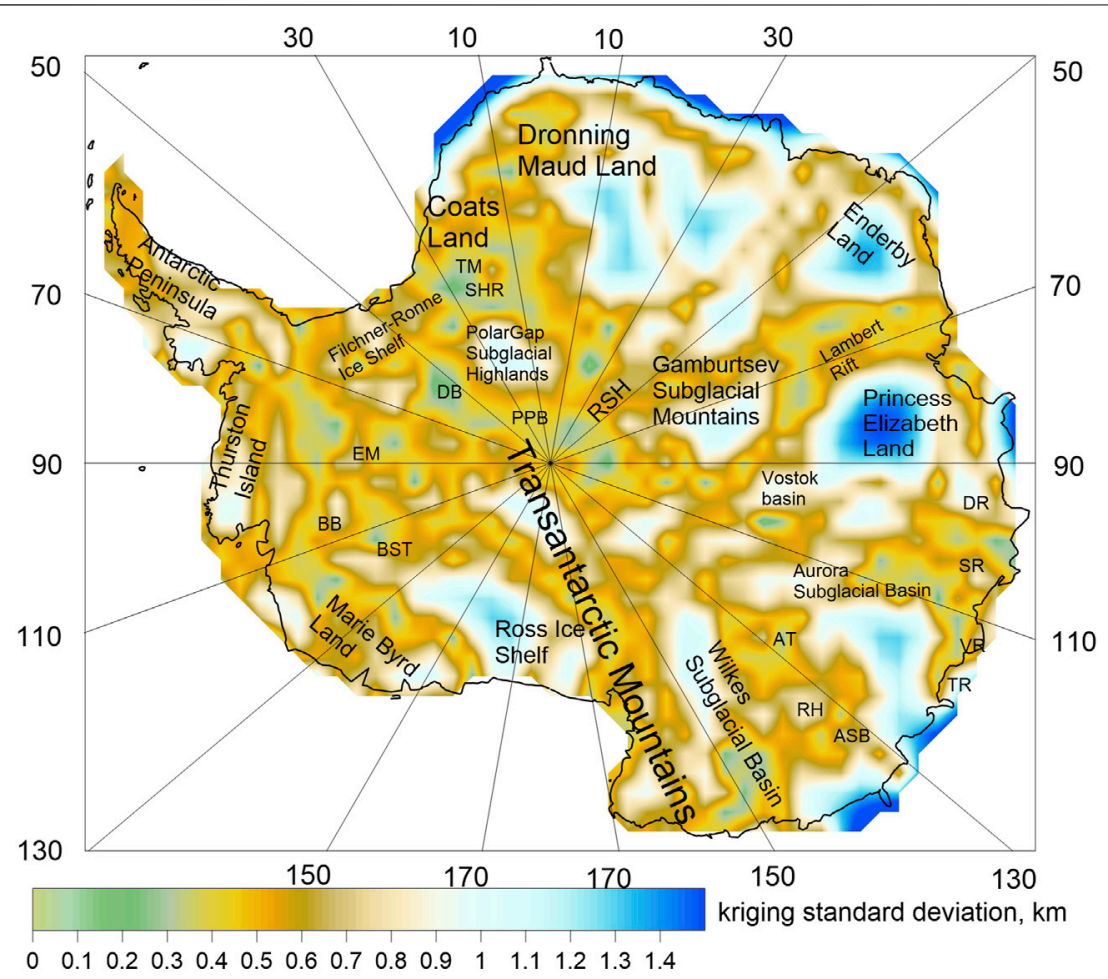

FIGURE 2 | Map of kriging standard deviation. It is used the same abbreviations as in Figure 1.

unlike the other East Antarctic rifts, has a latitudinal strike similar to Coats Land rifts. This rift has probably formed during Late Paleozoic-Early Mesozoic, such as Lambert Rift (Boger and Wilson, 2003; Lisker et al., 2003). Gravity and magnetic data suggest that the thickness of sedimentary rocks within the rift can exceed $4 \mathrm{~km}$ (Golynsky and Golynsky, 2019).

The Adventure Trench at $132^{\circ} \mathrm{E}$ is located in the intracontinental realm inside the Australo-Antarctic block. Gravity and magnetic data suggest $2-4 \mathrm{~km}$ of sediments here (Ferraccioli et al., 2001; Studinger et al., 2004).

The Astrolabe Subglacial Basin is another isolated deep depression between Adventure Trench and Resolution Highlands. According to magnetic data and low subglacial relief we suggest sediment thickness of $2-4 \mathrm{~km}$ here too (Aitken et al., 2014).

The Wilkes Basin is a broad area between Transantarctic Mountains and Aurora Basin with negative subglacial relief (Morlighem et al., 2020) and deep trenches due to possible processes of continental rifting (Ferraccioli et al., 2001). This basin lies sub-parallel to the Transantarctic Mountains and the West Antarctic Rift System. Radar, gravity and magnetic data predict 1-4 km thickness of sediments for the Wilkes basin, interpreted mainly as Beacon Supergroup (Ferraccioli et al., 2001; Ferraccioli et al., 2009; Frederick et al., 2016). Thickness of sediments for the Central basin is about $1-2 \mathrm{~km}$, whereas for the Western Basin it is about 2-4 km.

The Pensacola-Pole Basin (PPB) is located in proximity to the Transantarctic Mountains near the South Pole. New radar data reveal an elongated subglacial basin with an average subglacial relief of $-500 \mathrm{~m}$ (Morlighem et al., 2020), lying between Dufek Block, Polargap Subglacial Highlands, Recovery Subglacial Highlands, Pensacola Mountains and South Pole. Seismic refraction (Bentley, 1973), gravity, radar and magnetic studies (Wannamaker et al., 2004; Paxman et al., 2019) indicate that this sedimentary basin has thickness of about $1-2 \mathrm{~km}$.

\section{West Antarctica}

In West Antarctica, the ice sheet is grounded below sea level in most parts, so that the basal sediment layer is even more relevant for its evolution than in East Antarctica. The West Antarctic Rift System is the most dominant and relevant tectonic feature connected to sedimentary basins. These basins have low subglacial relief, and their sediments are due to rifting processes. At the Ross Ice Shelf, the sediment thickness reaches $6 \mathrm{~km}$ according to seismic data (Bentley, 1973; Rooney et al., 1987; Beaudoin et al., 1992; Munson and Bentley, 1992; Brink et al., 1993; Shen et al., 2018). The Byrd Subglacial Basin and Bentley Subglacial Trench have very low subglacial topography (up to $-2,500 \mathrm{~m}$; Morlighem et al., 2020). The sedimentary layer here is about $2-4 \mathrm{~km}$ thick (Bentley, 1973). The area below the Filchner-Ronne Ice Shelf is another large sedimentary basin. The sedimentary properties change along the seismic profiles near the coastline from Antarctic Peninsula to Coats Land (Huebscher et al., 1996; Leitchenkov and Kudryavtzev, 1997; Jokat and Herter, 2016). At the center of the basin, the thickness of sediments reaches more than $12 \mathrm{~km}$ 

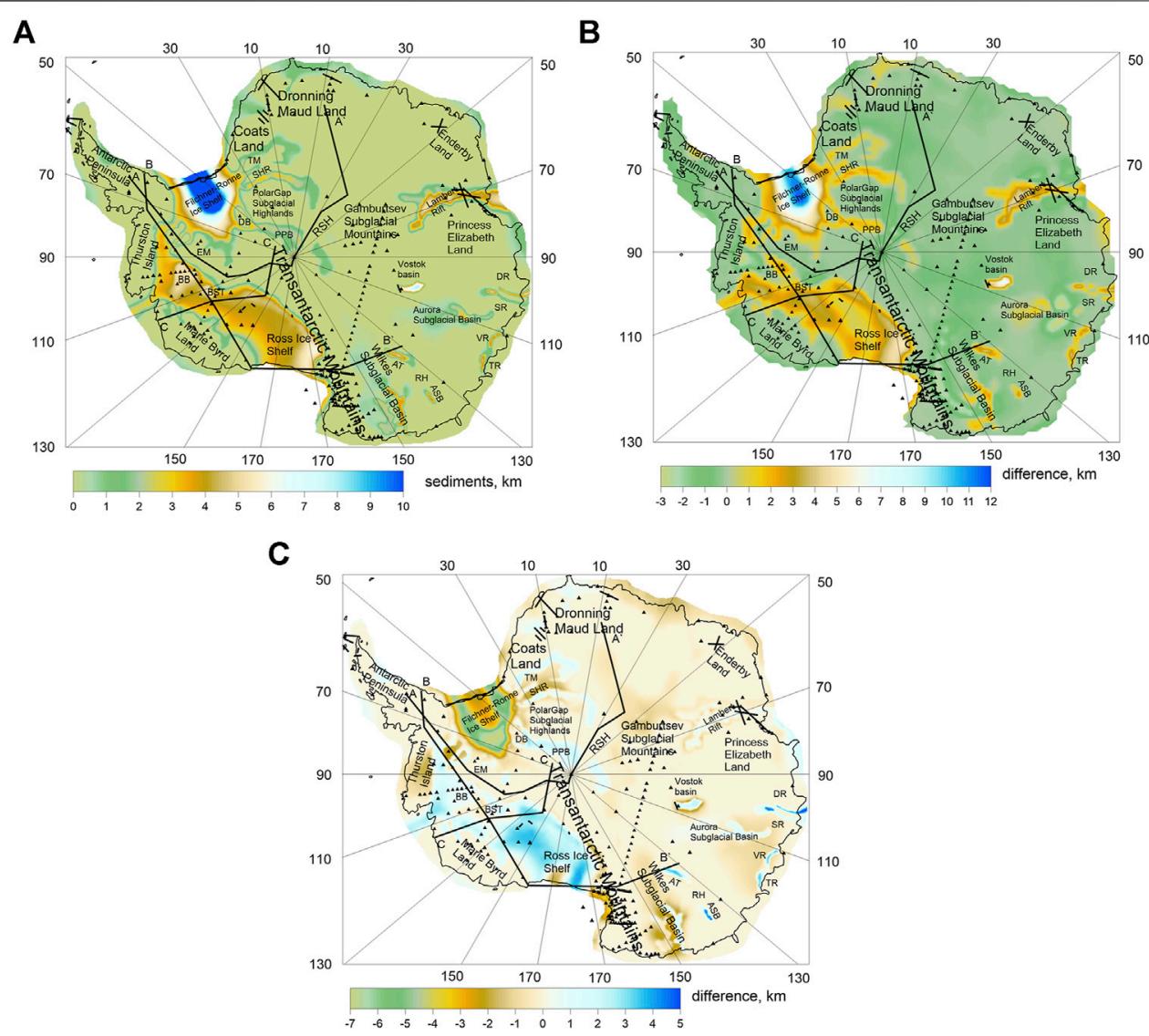

FIGURE 3 | (A) Map of a sediment thickness for Antarctica (ANTASed). It is used the same abbreviations as in Figure 1. (B) Difference between ANTASed model and the CRUST 1.0 model. (C) Difference between ANTASed and preliminary sediment model from Baranov et al. (2018a).

(Huebscher et al., 1996; Leitchenkov and Kudryavtzev, 1997). According to magnetic and seismic Rayleigh wave studies the sedimentary basin continues to the south until Elsworth Mountains and Dufek block with a continuation into Coats Land of East Antarctica and between Ellsworth Mountains and Antarctic Peninsula (Golynsky and Aleshkova, 1997; Shen et al., 2018).

For the CRUST 1.0 model, the average sediment thickness in the Antarctic continent is about $0.58 \mathrm{~km}$ with maxima up to $5 \mathrm{~km}$, while our results (Figure 3A) indicate that the average sediment thickness is about $0.77 \mathrm{~km}$ with maxima up to $12 \mathrm{~km}$ under the Filchner-Ronne Ice Shelf. Our model reveals significant differences with respect to both CRUST1.0 (see Figure 3B) and the previous sediment model by Baranov et al., 2018a (Figure 3C). In CRUST1.0, mainly based on the 1985 AAPG Tectonic Map of the World assembled for Exxon (Laske et al., 2013), several sedimentary basins in East Antarctica are not represented at all-Adventure, Astrolabe and Vostok subglacial basins, rifts of East Antarctica except Lambert Rift, basins of Coats Land. At the same time, in our ANTASed model, sedimentary basins from CRUST1.0 are shown in more detail (Lambert Rift, Aurora, Wilkes, Pensacola-Pole, Filchner-Ronne, Byrd, Bentley and Ross basins). Difference between ANTASed and CRUST1.0 may amount up to $10 \mathrm{~km}$, with average $0.19 \mathrm{~km}$ (standard deviation $1.53 \mathrm{~km}$ ), that we mainly attribute to the improved resolution of our model (see Figure 3B). There are significant differences in regions such as under the FilchnerRonne Ice Shelf (4-12 km), Lambert, Denman, Scott, Vanderford and Totten Rifts (up to $4 \mathrm{~km}$ ), under the Ross Ice Shelf (up to $4 \mathrm{~km}$ ), Wilkes, Bentley and Byrd basins (2-3 km); Pensacola-Pole basin $(1-2 \mathrm{~km})$, basins of Coats Land $(2-3 \mathrm{~km})$.

For the Filchner Ronne Ice Shelf area, the Exxon map used to build CRUST1.0 (https://www.worldcat.org/title/tectonic-mapof-the-world/oclc/32224099) delineates two separate sedimentary basins, the Ronne and the Filchner basins, while according to more recent seismic data we have a single, continuous, basin (Huebscher et al., 1996; Leitchenkov and Kudryavtzev, 1997). At the time of Exxon map creation these seismic profiles did not exist and it was suggested that Berkner Island is a natural boundary between these sedimentary basins. This explains the large difference between the CRUST1.0 sediment model (Laske et al., 2013) and ANTASed, up to $10 \mathrm{~km}$. In the preliminary sediment model by Baranov et al. (2018a) part of the sedimentary basins of East Antarctica is also missing (Astrolabe basin, rifts of East Antarctica except Lambert Rift, Pensacola-Pole and basins of Coats Land).

In our new model other sedimentary basins are mapped with more details (Lambert Rift, Aurora, Wilkes, Filchner-Ronne, 


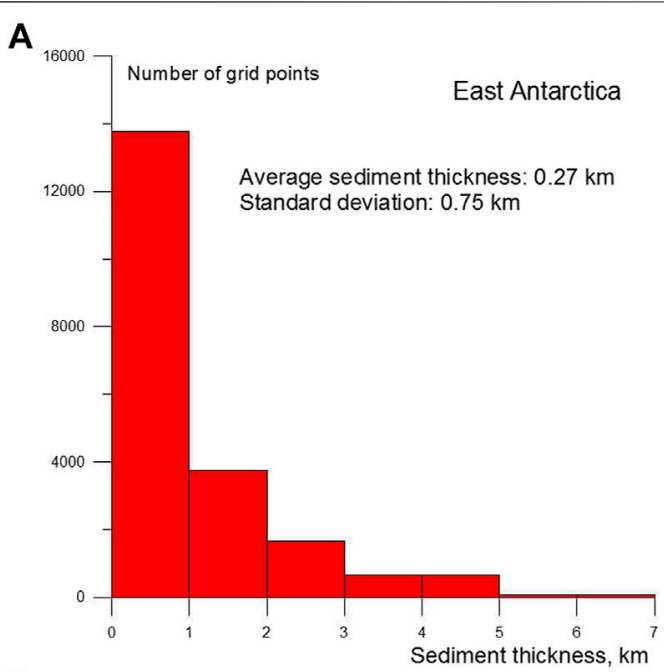

B

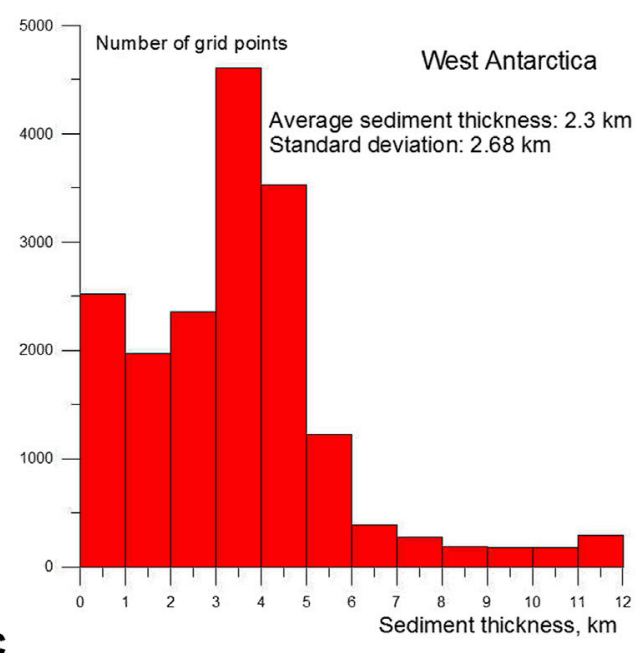

C

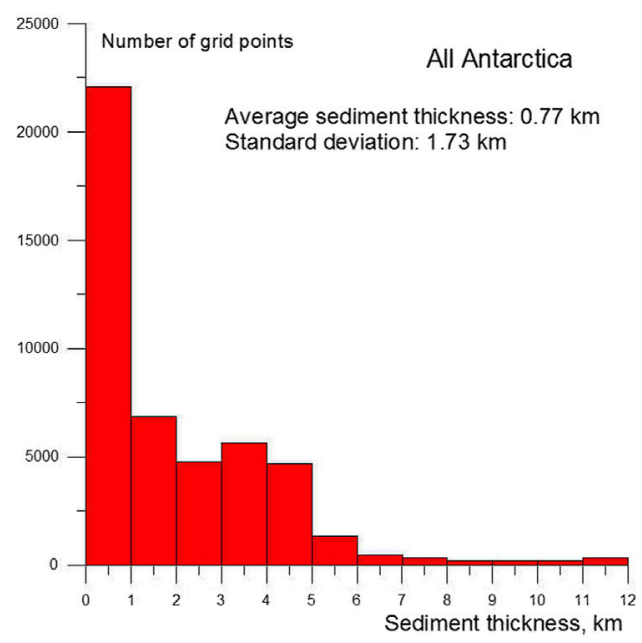

FIGURE 4 | Histograms of the total sediment thickness for (A) East Antarctica, (B) West Antarctica and the whole continent (C)
Byrd, Bentley and Ross basins). Although the entire Wilkes Basin had previously been considered a wide sedimentary basin, newer data show that sediments are mainly located in narrow and deep grabens (Western and Central Basins) of the Wilkes lowland. A similar situation is also true for the Aurora basin. Adventure basin is deeper than in the previous model by Baranov et al. (2018a). Deep and narrow rifts of East Antarctica have properly been recognized in the BEDMACHINE model (Morlinghem et al., 2020). Additional data reveals sediments for these rifts. The boundaries and sediment thickness for the Filcher-Ronne Ice basin are identified by new geophysical data (Jokat and Herter, 2016).

The difference between ANTASed and the preliminary sediment model by Baranov et al. (2018a) is $-7 /+5 \mathrm{~km}$ with average $-0.06 \mathrm{~km}$ (standard deviation $1.1 \mathrm{~km}$ ) mainly due to the improved resolution of our model (see Figure 3C). There are significant differences in regions such as under the Filchner-Ronne Ice Shelf ( -2 to $-7 \mathrm{~km})$, Denman, Scott, Vanderford and Totten rifts (up to $4 \mathrm{~km}$ ), under the Ross Ice Shelf $(-2$ to $+2 \mathrm{~km})$, Wilkes, Bentley and Byrd basins ( -2 to $+2 \mathrm{~km}$ ), Pensacola-Pole basin $(1-2 \mathrm{~km})$, Vostok basin ( -2 to $+2 \mathrm{~km})$, Adventure basin $(2-3 \mathrm{~km})$; basins of Coats Land (-2 to $+2 \mathrm{~km}$ ).

Figure 4 shows the frequency distribution of sediment thickness for East Antarctica, West Antarctica, and for the whole continent. The average sediment thickness of West Antarctica is about $2.3 \mathrm{~km}$ (standard deviation $2.68 \mathrm{~km}$ ) due to large sedimentary basins. The average sediment thickness of East Antarctica is about $0.27 \mathrm{~km}$ (standard deviation $0.75 \mathrm{~km}$ ).

\section{DISCUSSION AND CONCLUSION}

We have collected and analyzed different geophysical data: subglacial bedrock relief, gravity, radar, magnetic, and seismic data to provide a regional sediment model of the Antarctic continent. The new sediment thickness grid, ANTASed, is then built, analyzed and compared with previous models. The bulk of the sediments in Antarctica belongs to the Beacon Supergroup, in addition to them, there are also younger Mesozoic and Cenozoic sediments.

Our results, based on the combined processing of geophysical data (see Figure 1), reveal significant differences between the sediment structure of East and West Antarctica. The dimensions of sedimentary basins are determined by the degree of crustal extension - rather moderate for East Antarctica (up to $7 \mathrm{~km}$ for Vostok basin) and significantly higher for West Antarctica (up to $12 \mathrm{~km}$ for the region below the Ronne Ice Shelf).

The main sedimentary basins are concentrated in broad areas of extension in the West Antarctic Rift System with low subglacial relief (Ross, Filchner-Ronne, Bentley and Byrd basins and their extensions) and in the lowlands of the 
Australo-Antarctica block of East Antarctica.

According to our results, West Antarctica contains wide sedimentary basins: the Ross basin (thickness 2-6 km); the Filchner-Ronne basin with its continuations to the Antarctic Peninsula; South Pole and Coats Land $(2-12 \mathrm{~km})$, Bentley and Byrd basins $(2-5 \mathrm{~km})$. Maximum sediment thickness is reached under the Filchner-Ronne Ice Shelf (up to $12 \mathrm{~km}$ ) with a complex multi-layered structure.

For East Antarctica there are both narrow sediment-filled rifts: JutulStraumen (thickness 1-2 km), Lambert (2-5 km), Scott, Denman, Vanderford and Totten $(2-4 \mathrm{~km})$; and wider areas such as the Vostok $(2-7 \mathrm{~km})$, Aurora $(1-3 \mathrm{~km})$, Astrolabe $(2-4 \mathrm{~km})$, Adventure $(2-4 \mathrm{~km})$ and Wilkes $(1-4 \mathrm{~km})$ basins, corresponding to the Australo-Antarctica block of East Antarctica.

The average sediment thickness for Antarctica is about 0.77 $\mathrm{km}$, for West Antarctica $2.3 \mathrm{~km}$, for East Antarctica $0.27 \mathrm{~km}$. Compared to previous models CRUST1.0 (Laske et al., 2013) and ANTACrust (Baranov et al., 2018a), we recognize the new Pensacola-Pole, Coats Land, Denman, Scott, Adventure, Astrolabe, Vanderford and Totten sedimentary basins in East Antarctica. The resolution of the sediment map is also improved. Differences between ANTASed and previous models reach +12 / $-3 \mathrm{~km}$ for CRUST 1.0 (Laske et al., 2013) and $+5 /-7 \mathrm{~km}$ for ANTACrust (Baranov et al., 2018a) respectively. By integrating a wide range of specific geophysical and geological information, ANTASed provides significant improvements over global models for sediments in Antarctica.

The ANTASed model also complements the new three-layer crustal model for Antarctica (Baranov et al., 2021) and sediment

\section{REFERENCES}

Aitken, A. R. A., Young, D. A., Ferraccioli, F., Betts, P. G., Greenbaum, J. S., Richter, T. G., et al. (2014). The Subglacial Geology of Wilkes Land, East Antarctica. Geophys. Res. Lett. 41, 2390-2400. doi:10.1002/2014gl059405

An, M., Wiens, D. A., Zhao, Y., Feng, M., Nyblade, A. A., Kanao, M., et al. (2015). S -velocity Model and Inferred Moho Topography Beneath the Antarctic Plate from Rayleigh Waves. J. Geophys. Res. Solid Earth. 120 (1), 359-383. doi:10.1002/2014jb011332

Anandakrishnan, S., Blankenship, D. D., Alley, R. B., and Stoffa, P. L. (1998). Influence of Subglacial Geology on the Position of a West Antarctic Ice Stream from Seismic Observations. Nature 394, 62-65. doi:10.1038/27889

Aster, R. C., and Winberry, J. P. (2017). Glacial Seismology. Rep. Prog. Phys. 80, aa8473. doi:10.1088/1361-6633/aa8473

Bamber, J. L., Ferraccioli, F., Joughin, I., Shepherd, T., Rippin, D. M., Siegert, M. J., et al. (2006). East Antarctic Ice Stream Tributary Underlain by Major Sedimentary Basin. Geol. 34, 33-36. doi:10.1130/g22160.1

Baranov, A. (2010). A New Crustal Model for Central and Southern Asia. Izvest. Phys. Solid Earth. 46, 34-46. doi:10.1134/S106935131

Baranov, A., Tenzer, R., and Bagherbandi, M. (2018a). Combined GravimetricSeismic Crustal Model for Antarctica. Surv. Geophys. 39, 23-56. doi:10.1007/ s10712-017-9423-5

Baranov, A., Bagherbandi, M., and Tenzer, R. (2018b). Combined GravimetricSeismic Moho Model of Tibet. Geosciences 8, 461. doi:10.3390/ geosciences 8120461

Baranov, A., and Morelli, A. (2013). The Moho Depth Map of the Antarctica Region. Tectonophysics 609, 299-313. doi:10.1016/j.tecto.2012.12.023

Baranov, A., Tenzer, R., and Morelli, A. (2021). Updated Antarctic Crustal Model. Gondwana Res. 89, 1-18. doi:10.1016/j.gr.2020.08.010 model for surrounding ocean (Straume et al., 2019). We provide our sediment map for Antarctica and hope that it will be useful to scientists (https://www.itpz-ran.ru/en/activity/current-projects/ antased-a-new-sediment-model-for-antarctica/). Nevertheless, we recognize that new data are still needed to add information particularly in the central parts of Antarctica.

\section{DATA AVAILABILITY STATEMENT}

The original contributions presented in the study are included in the article/Supplementary Material, further inquiries can be directed to the corresponding author.

\section{AUTHOR CONTRIBUTIONS}

$\mathrm{AB}$ designed and performed calculations of the maps, provided a main framework of the research. AM provided a general leadership and corrected the manuscript. AC provided a BEDMACHINE data and corrected the manuscript.

\section{ACKNOWLEDGMENTS}

We thank two reviewers for constructive comments which helped to improve the manuscript. The study was performed under a government contract of the Schmidt Institute of Physics of the Earth of the Russian Academy of Sciences.

Bassin, C., Laske, G., Eckstaller, A., and Masters, G. (2000). The Current Limits of Resolution for Surface Wave Tomography in North America. EOS Trans. AGU 81, F897.

Bayer, B., Geissler, W. H., Eckstaller, A., and Jokat, W. (2009). Seismic Imaging of the Crust Beneath Dronning Maud Land, East Antarctica. Geophys. J. Int. 178, 860-876. doi:10.1111/j.1365-246x.2009.04196.x

Beaudoin, B. C., ten Brink, U. S., and Stern, T. A. (1992). Characteristics and Processing of Seismic Data Collected on Thick, Floating Ice: Results from the Ross Ice Shelf, Antarctica. Geophysics 57, 1359-1372. doi:10.1190/1.1443205

Becker, T. W. (2012). On Recent Seismic Tomography for the Western United States. Geochem. Geophys. Geosyst. 13, 1, Q01W10. doi:10.1029/2011gc003977

Bentley, C. R. (1973). Crustal Structure of Antarctica. Tectonophysics 20, 229-240. doi:10.1016/0040-1951(73)90112-1

Boger, S. D., and Wilson, C. J. L. (2003). Brittle Faulting in the Prince Charles Mountains, East Antarctica: Cretaceous Transtensional Tectonics Related to the Break-Up of Gondwana. Tectonophysics 367, 173-186. doi:10.1016/s0040-1951(03)00125-2

Brink, U. S. t., Bannister, S., Beaudoin, B. C., and Stern, T. A. (1993). Geophysical Investigations of the Tectonic Boundary Between East and West Antarctica. Science 261, 45-50. doi:10.1126/science.261.5117.45

Chuvaev, A., Baranov, A., and Bobrov, A. (2020). Numerical Modelling of Mantle Convection in the Earth Using Cloud Technologies. Comput. Tech. 25 (2), 103-118. doi:10.25743/ICT.2020.25.2.009

Collinson, J. W., Isbell, J. L., Elliot, D. H., Miller, M. F., Miller, J. M. G., and Veevers, J. J. (1994). Permian-Triassic Transantarctic Basin. Geol. Soc. Am. Mem. 184, 173-222. doi:10.1130/mem184-p173

Cressie, N. (1990). The Origins of Kriging. Math. Geol. 22 (3), 239-252. doi:10.1007/bf00889887

Danesi, S., and Morelli, A. (2001). Structure of the Upper Mantle under the Antarctic Plate From Surface Wave Tomography. Geophys. Res. Lett. 28, 4395-4398. doi:10.1029/2001gl013431 
Davey, F. J., Cande, S. C., and Stock, J. M. (2006). Extension in the Western Ross Sea Region-, L20315 Region-Links between Adare Basin and Victoria Land Basin. Geophys. Res.Lett. 33, L20315. doi:10.1029/2006GL027383

Faccenna, C., Rossetti, F., Becker, T. W., Danesi, S., and Morelli, A. (2008). Recent Extension Driven by Mantle Upwelling Beneath the Admiralty Mountains (East Antarctica). Tectonics 27 (4), 1-13. doi:10.1029/2007tc002197

Ferraccioli, F., Armadillo, E., Jordan, T., Bozzo, E., and Corr, H. (2009). Aeromagnetic Exploration over the East Antarctic Ice Sheet: A New View of the Wilkes Subglacial Basin. Tectonophysics 478, 62-77. doi:10.1016/ j.tecto.2009.03.013

Ferraccioli, F., Coren, F., Bozzo, E., Zanolla, C., Gandolfi, S., Tabacco, I., et al. (2001). Rifted(?) Crust at the East Antarctic Craton Margin: Gravity and Magnetic Interpretation along a Traverse across the Wilkes Subglacial Basin Region. Earth Planet. Sci. Lett. 192, 407-421. doi:10.1016/s0012-821x(01) 00459-9

Filina, I. Y., Blankenship, D. D., Thoma, M., Lukin, V. V., Masolov, V. N., and Sen, M. K. (2008). New 3D Bathymetry and Sediment Distribution in Lake Vostok: Implication for Pre-glacial Origin and Numerical Modeling of the Internal Processes Within the Lake. Earth Planet. Sci. Lett. 276, 106-114. doi:10.1016/ j.epsl.2008.09.012

Frederick, B. C., Young, D. A., Blankenship, D. D., Richter, T. G., Kempf, S. D., Ferraccioli, F., et al. (2016). Distribution of Subglacial Sediments across the Wilkes Subglacial Basin, East Antarctica. J. Geophys. Res. Earth Surf. 121, 790-813. doi:10.1002/2015jf003760

Fretwell, P., Pritchard, H. D., Vaughan, D. G., Bamber, J. L., Barrand, N. E., Bell, R., et al. (2013). Bedmap2: Improved Ice Bed, Surface and Thickness Datasets for Antarctica. Cryosphere Discuss 6, 4305-4361. doi:10.5194/tc-7-375-2013

Golynsky, A. V., and Aleshkova, N. D. (1997). Regional Magnetic Anomalies of the Weddell Sea Region and Their Geological Significance. Polarforschung 67, 101-117. doi:10.2312/polarforschung.67.3.101

Golynsky, D. A., and Golynsky, A. V. (2012). East Antarctic Rift Systems - Key to Understanding of Gondwana Break-Up. Reg. Geol. Metallogeny. 52, 58-72.

Golynsky, D. A., and Golynsky, A. V. (2019). Unique Geological Structures of the Law Dome and Vanderford and Totten Glaciers Region (Wilkes Land) Distinguished by Geophysical Data. Problemy Arktiki $i$ Antarktiki 65, 212-231. doi:10.30758/0555-2648-2019-65-2-212-231

Granot, R., Cande, S. C., Stock, J. M., and Damaske, D. (2013a). Revised EoceneOligocene Kinematics for the West Antarctic Rift System. Geophys. Res. Lett. 40, 279-284. doi:10.1029/2012GL054181

Granot, R., Cande, S. C., Stock, J. M., and Damaske, D. (2013b). Revised EoceneOligocene Kinematics for the West Antarctic Rift System. Geophys. Res. Lett. 40, 279-284. doi:10.1029/2012gl054181

Harrowfield, M., Holdgate, G. R., Wilson, C. J. L., and McLoughlin, S. (2005). Tectonic Significance of the Lambert Graben, East Antarctica: Reconstructing the Gondwanan Rift. Geology 33, 197-200. doi:10.1130/g21081.1

Hartley, R. W., and Allen, P. A. (1994). Interior Cratonic Basins of Africa: Relation to continental Break-Up and Role of Mantle Convection. Basin Res. 6, 95-113. doi:10.1111/j.1365-2117.1994.tb00078.x

Holdgate, G. R., McLoughlin, S., Drinnan, A. N., Finkelman, R. B., Willett, J. C., and Chiehowsky, L. A. (2005). Inorganic Chemistry, Petrography and Palaeobotany of Permian Coals in the Prince Charles Mountains, East Antarctica. Int. J. Coal Geol. 63, 156-177. doi:10.1016/j.coal.2005.02.011

Hole, M. J., and LeMasurier, W. E. (1994). Tectonic Controls on the Geochemical Composition of Cenozoic, Mafic Alkaline Volcanic Rocks from West Antarctica. Contr. Mineral. Petrol. 117, 187-202. doi:10.1007/bf00286842

Huebscher, C., Jokat, W., and Miller, H. (1996). "Structure and Origin of Southern Weddell Sea Crust: Results and Implications," in Weddell Sea Tectonics and Gondwana Break-Up. Editors B. C. Storey, E. C. King, and R. A. Livermore (London, United Kingdom: Geological Society, London, Special Publications), 108, 201-212.

Huerta, A. D., and Harry, D. L. (2007). The Transition From Diffuse to Focused Extension: Modeled Evolution of the West Antarctic Rift System. Earth Planet. Sci. Lett. 255, 133-147. doi:10.1016/j.epsl.2006.12.011

Hungeling, A., and Tyssen, F. (1991). "Reflection Seismic Measurements in Western Neuschwabenland," in Geological Evolution of Antarctica. Proceedings of the Fifth International Symposium on Antarctic Earth Sciences. Editors M. R. Thornson, J. A. Crame, and J. W. Thomson
(Cambridge, United Kingdom: Robinson College, Cambridge, Cambridge University Press), 73.

Isanina, E., Krupnova, N., Popov, S., Masolov, V., and Lukin, V. (2009). Deep Structure of the Vostok Basin, East Antarctica as Deduced from Seismological Observations. Geotektonika. 3, 45-50. doi:10.1134/S0016852109030042

Jokat, W., and Herter, U. (2016). Jurassic Failed Rift System below the FilchnerRonne-Shelf, Antarctica: New Evidence From Geophysical Data. Tectonophysics 688, 65-83. doi:10.1016/j.tecto.2016.09.018

Jordan, T. A., Ferraccioli, F., Vaughan, D. G., Holt, J. W., Corr, H., Blankenship, D. D., et al. (2010). Aerogravity Evidence for Major Crustal Thinning Under the Pine Island Glacier Region (West Antarctica). Geol. Soc. Am. Bull. 122 (5-6), 714-726. doi:10.1130/B26417.1

Jordan, T. A., Riley, T. R., and Siddoway, C. S. (2020). The Geological History and Evolution of West Antarctica. Nat. Rev. Earth Environ. 1, 117-133. doi:10.1038/ s43017-019-0013-6

Joughin, I., and Alley, R. B. (2011). Stability of the West Antarctic Ice Sheet in a Warming World. Nat. Geosci. 4, 506-513. doi:10.1038/ngeo1194

Kanao, M., Fujiwara, A., Miyamachi, H., Toda, S., Ito, K., Tomura, M., et al. (2011). Reflection Imaging of the Crust and the Lithospheric Mantle in the LützowHolm Complex, Eastern Dronning Maud Land, Antarctica, Derived from the SEAL Transects. Tectonophysics 508, 73-84. doi:10.1016/j.tecto.2010.08.005

Kogan, A. (1971). First Experience in Crustal Investigation for Antarctica by Deep Seismic Sounding. Russ. Geol. Geophys. 10, 84-89.

Kolmakov, A., Mishenkin, B., and Solovyev, D. (1975). Deep Seismic Studies in East Antarctica. Bull. Soviet Antarc. Exped. 91, 5-15.

Kudryavtzev, G., Butzenko, V., and Kadmina, I. (1991). "Crustal Section across Western Dronning Maud Land continental Margin from Geophysical Data,” in Proceedings of the Sixth International Symposium on Antarctic Earth Science, Abstracts. Editors Y. Yoshida, K. Kaminuma, and K. Shiraishi (Tokyo: National Institute for Polar Research), 330-335.

Laske, G., Ma, Z., Masters, G., and Pasyanos, M. E. (2013). CRUST1.0: A New Global Crustal Model at 1x1 Degrees. Available at: https://igppweb.ucsd.edu/ $\sim$ gabi/crust1.html.

Laske, G., and Masters, G. (1997). A Global Digital Map of Sediment Thickness. Eos, Trans. Am. Geophys. Union. 78, F483.

Leitchenkov, G., and Kudryavtzev, G. (1997). Structure and Origin of the Earth's Crust in the Weddell Sea Embayment (Beneath the Front of the Filchner and Ronne Ice Shelves) from Deep Seismic Sounding Data. Polarforschung 67, 3143-3154.

LeMasurier, W. E. (2008). Neogene Extension and basin Deepening in the West Antarctic Rift Inferred From Comparisons With the East African Rift and Other Analogs. Geology 36 (3), 247-250. doi:10.1130/ g24363a.1

Lisker, F., Brown, R., and Fabel, D. (2003). Denudation and thermal History along a Transect across the Lambert Graben, Northern Prince Charles Mountains, Antarctica, Derived from Apatite Fission Track Thermochronology. Tectonics 22, 1055. doi:10.1029/2002tc001477

Lucas, E. M., Soto, D., Nyblade, A. A., Lloyd, A. J., Aster, R. C., Wiens, D. A., et al. (2020). P- and S-Wave Velocity Structure of central West Antarctica: Implications for the Tectonic Evolution of the West Antarctic Rift System. Earth Planet. Sci. Lett. 546, 116437. doi:10.1016/j.epsl.2020.116437

Mishra, D. C., Chandra Sekhar, D. V., Venkata Raju, D. C., and Vijaya Kumar, V. (1999). Crustal Structure Based on Gravity-Magnetic Modelling Constrained From Seismic Studies under Lambert Rift, Antarctica and Godavari and Mahanadi Rifts, India and Their Interrelationship. Earth Planet. Sci. Lett. 172, 287-300. doi:10.1016/s0012-821x(99)00212-5

Morelli, A., and Danesi, S. (2004). Seismological Imaging of the Antarctic Continental Lithosphere: a Review. Glob. Planet. Change. 42, 155-165. doi:10.1016/j.gloplacha.2003.12.005

Morlighem, M., Rignot, E., Binder, T., Blankenship, D., Drews, R., Eagles, G., et al. (2020). Deep Glacial Troughs and Stabilizing Ridges Unveiled Beneath the Margins of the Antarctic Ice Sheet. Nat. Geosci. 13, 132-137. doi:10.1038/ s41561-019-0510-8

Munson, C. G., and Bentley, C. R. (1992). "The Crustal Structure beneath Ice Stream C and ridge BC, West Antarctica from a Seismic Refraction and Gravity Profile," in Recent Progress in Antarctic Earth Science. Editors Y. Yoshida, K Kaminuma, and K Shiraishi (Tokyo: TERRAPUB), 507-514 
Paxman, G. J. G., Jamieson, S. S. R., Ferraccioli, F., Jordan, T. A., Bentley, M. J., Ross, N., et al. (2019). Subglacial Geology and Geomorphology of the Pensacola Pole Basin, East Antarctica. Geochem. Geophys. Geosyst. 20, 1-22. doi:10.1029/ $2018 \mathrm{gc008126}$

Powell, C. M., Roots, S. R., and Veevers, J. J. (1988). Pre-Breakup Continental Extension in East Gondwanaland and the Early Opening of the Eastern Indian Ocean. Tectonophysics 155, 261-283. doi:10.1016/0040-1951(88)90269-7

Rooney, S. T., Blankenship, D. D., and Bentley, C. R. (1987). "Seismic Refraction Measurements of Crustal Structure in West Antarctica," in Gondwana Six: Structure, Tectonics and Geophysics, Geophysical Monograph Series 40. Editor G. D. McKenzie, 1-7.

Scheinert, M., Ferraccioli, F., Schwabe, J., Bell, R., Studinger, M., Damaske, D., et al. (2016). New Antarctic Gravity Anomaly Grid for Enhanced Geodetic and Geophysical Studies in Antarctica. Geophys. Res. Lett. 43, 600-610. doi:10.1002/ $2015 \mathrm{gl} 1067439$

Shen, W., Wiens, D. A., Anandakrishnan, S., Aster, R. C., Gerstoft, P., Bromirski, P. D., et al. (2018). The Crust and Upper Mantle Structure of central and West Antarctica From Bayesian Inversion of Rayleigh Wave and Receiver Functions. J. Geophys. Res. Solid Earth 123, 7824-7849. doi:10.1029/2017jb015346

Shepherd, T., Bamber, J., and Ferraccioli, F. (2006). Subglacial Geology in Coats Land, East Antarctica, Revealed by Airborne Magnetics and Radar Sounding. Earth Planet. Sci. Lett. 244, 323-335. doi:10.1016/j.epsl.2006.01.068

Straume, E. O., Gaina, C., Medvedev, S., Hochmuth, K., Gohl, K., Whittaker, J. M., et al. (2019). GlobSed: Updated Total Sediment Thickness in the World's Oceans. Geochem. Geophys. Geosyst. 20, 1756. doi:10.1029/2018gc008115

Studinger, M., Bell, R. E., Blankenship, D. D., Finn, C. A., Arko, R. A., Morse, D. L., et al. (2001). Subglacial Sediments: A Regional Geological Template for Ice Flow in West Antarctica. Geophys. Res. Lett. 28, 3493-3496. doi:10.1029/ $2000 \mathrm{gl} 011788$

Studinger, M., Bell, R. E., Buck, W. R., Karner, G. D., and Blankenship, D. D. (2004). Sub-Ice Geology Inland of the Transantarctic Mountains in Light of New Aerogeophysical Data. Earth Planet. Sci. Lett. 220, 391-408. doi:10.1016/ s0012-821x(04)00066-4
Tabacco, I. E., Cianfarra, P., Forieri, A., Salvini, F., and Zirizotti, A. (2006). Physiography and Tectonic Setting of the Subglacial Lake District Between Vostok and Belgica Subglacial Highlands (Antarctica). Geophys. J. Int. 165 (3), 1029-1040. doi:10.1111/j.1365-246X.2006.02954.x

Tinto, K. J., Padman, L., Siddoway, C. S., Springer, S. R., Fricker, H. A., Das, I., et al. (2019). Ross Ice Shelf Response to Climate Driven by the Tectonic Imprint on Seafloor Bathymetry. Nat. Geosci. 12, 441-449. doi:10.1038/s41561-019-0370-2

Wannamaker, P. E., Stodt, J. A., Pellerin, L., Olsen, S. L., and Hall, D. B. (2004). Structure and Thermal Regime Beneath the South Pole Region, East Antarctica, From Magnetotelluric Measurements. Geophys. J. Int. 157, 36-54. doi:10.1111/ j.1365-246x.2004.02156.x

Whitehead, J. M., Quilty, P. G., Mckelvey, B. C., and O’Brien, P. E. (2006). A Review of the Cenozoic Stratigraphy and Glacial History of the Lambert Graben-Prydz Bay Region, East Antarctica. Antartic Sci. 18, 83-99. doi:10.1017/ s0954102006000083

Conflict of Interest: The authors declare that the research was conducted in the absence of any commercial or financial relationships that could be construed as a potential conflict of interest.

Publisher's Note: All claims expressed in this article are solely those of the authors and do not necessarily represent those of their affiliated organizations, or those of the publisher, the editors and the reviewers. Any product that may be evaluated in this article, or claim that may be made by its manufacturer, is not guaranteed or endorsed by the publisher.

Copyright (c) 2021 Baranov, Morelli and Chuvaev. This is an open-access article distributed under the terms of the Creative Commons Attribution License (CC BY). The use, distribution or reproduction in other forums is permitted, provided the original author(s) and the copyright owner(s) are credited and that the original publication in this journal is cited, in accordance with accepted academic practice. No use, distribution or reproduction is permitted which does not comply with these terms. 